\title{
REPRESENTATIONS OF THE OTTOMANS IN THE RUSSIAN ORIENTALIST DISCOURSE IN THE FIRST HALF OF 19TH CENTURY
}

\author{
Marina KASUMOVA ${ }^{1}$
}

\begin{abstract}
The paper analyzes the main factors of European origin Orientalist discourse and the corresponding practices, current trends in the study of Eastern societies, study the process of formation and transformation in the Russian discourse representations of images of the East and the Ottoman Empire by means of concepts "Asian luxury", "Oriental eloquence" and "Eastern wisdom. "
\end{abstract}

Keywords: Russia, the Ottoman Empire, East, Orientalism, discourse representation.

Kasumova, Marina. "Reprezentacii Obrazov Osmanskoj Imperii V Rossijskom Orientalistskom Diskurse Pervoj Poloviny XIX Veka". Ídil 3.11 (2014): 169-190.

Kasumova, M. (2014). Reprezentacii Obrazov Osmanskoj Imperii V Rossijskom Orientalistskom Diskurse Pervoj Poloviny XIX Veka. Idil, 3 (11), s.169190.

\footnotetext{
${ }^{1}$ Doç. Dr. Fatih Üniversitesi. Fen - Edebiyat Fakültesi, Rus Dili ve Edebiyatı Bölümü. kasumova.@.mail.ru
} 


\title{
РЕПРЕЗЕНТАЦИИ ОБРАЗОВ ОСМАНСКОЙ ИМПЕРИИ В РОССИЙСКОМ ОРИЕНТАЛИСТСКОМ ДИСКУРСЕ ПЕРВОЙ ПОЛОВИНЫ ХІХ ВЕКА
}

\begin{abstract}
РЕЗЮМЕ
В статье анализируются основные факторы зарождения европейского ориенталистского дискурса и соответствующих ему практик, современные тенденции в исследовании восточных обществ; изучается процесс формирования и трансформации в российском дискурсе репрезентаций образов Востока и Османской империи при посредстве концептов «азиатская роскошь», «восточное красноречие» и «восточная мудрость».
\end{abstract}

Ключевые слова: Россия, Османская империя, Восток, ориентализм, дискурс, репрезентации. 
Взаимовлияние Запада и Востока, имея многовековую историю, происходило в самом широком социальном, политическом и культурном контекстах. Взаимодействие целого комплекса факторов развивалось в условиях полиморфизма, что, как правило, вело к противоречивым результатам. Стремительная интенсификация и трансформация контактов наиболее явственно стала проявляться в течение XVI - XIX веков.

Постепенное и последовательное осуществление универсального по масштабам и европейского по содержанию проекта «картографического знания» привело к тому, что мир стал визуализированной картографической реальностью. (Ballantyne 2002: 120) Созданный подобным образом и получивший массовое распространение посредством технологий «печатного капитализма» (Андерсон 2002) комплекс знаний, стал доступен для европейцев.

В данном контексте именно период второй половины XVIII и начала XIX веков стал наиболее важным в процессе роста и развития европейских знаний о мире. После эпохи количественного накопления фактов, начинается период их качественной систематизации.

Каталогизация, классификация и категоризация знаний в рамках складывающихся научного и гуманитарного дискурсов вводит каждую расу, народ, общество и государство в отведенное им место на карте, в каталоге, описи, коллекции, на эволюционной лестнице, на ступени общественного и исторического прогресса. Создается цельное восприятие мира.

Таким образом, новый этап в развитии знаний тождествен новому этапу взаимоотношений Запада и Востока. Конструируется и конституируется новый, неизбежно иерархический политический порядок, который разделяет мир.

Все это укрепляло представления европейцев о себе, как носителях некоей исторической миссии в отношении других отсталых, диких и варварских народов и государств.

Ведущую роль начинает играть идеи о «цивилизаторской миссии» Европы на Востоке. Это было свойственно колониальной историографии с ее явным акцентом на преобразующую роль белого человека - миссионера, администратора, предпринимателя - в прежде якобы инертном и статичном «туземном» окружении. 
В течение последних двух - трех десятилетий изучение феноменов колониальной экспансии и идеологии колониализма нового времени и в целом проблем взаимодействия Запада и Востока, Европы и Азии вышло на качественно новый уровень. Особенно значимым стал поворот историографии взаимоотношений Востока и Запада через междисциплинарные контакты к таким гуманитарным дисциплинам и направлениям, как антропология, литературоведение, регионоведение, исследования культуры (cultural studies), постструктуралистски-постмодернистская теория критического дискурса. (Kennedy 1996: 346). Сформировавшаяся таким образом, «теория колониального дискурса», подвергает полной деконструкции доминировавшие прежде представления Запада о Востоке и других неевропейских обществах. (Colonial Discourse and Post-Colonial Theory 1994, Colonial Discourse, Postcolonial Theory 1995)

Соответственно, теории «колониального дискурса», постколониальная теория акцентируются неизбежной относительности любого знания, которое всегда обусловлено совокупностью лингвистических форм, культурными репрезентациями и доминирующими позициями тех, кто это знание создает. С этой точки зрения обращение к прошлому не ставит цель установления научных истин, а ориентируется на поиск и выявление условий, которые создавали различные типы знаний о «Другом». Особое внимание обращается на раскрытие способов инструментализации знаний, репрезентировавших субъектов своего изучения, путем их объективизации, а также, на изучение отношений господства-подчинения, позволявших навязать свою волю и представления другим. (The New Cultural History 1989, Washbrook 1999: 596)

В знаменитой лекции М. Фуко «Что такое автор?», проводится исторический анализ понятия «автор», которое также рассматривает как функция, меняющаяся в зависимости от временного и социального контекстов. Метод дискурсивного анализа М. Фуко, рассматривающий текст не как что-то автономное, но исключительно как результат наличия в социуме определенной массы высказываний, оказал серьезное влияние на «политические» критики. Субъект рассказывающий заменяет собой рассказываемый объект и перехватывает, репрезентирует его опыт. Э. Саид в «Ориентализме» подверг критике господство репрезентации: когда «мы», цивилизованные европейцы репрезентируем «их», отсталых, застывших, неизменных в веках, обитателей Востока, в результате чего «они», предстают в виде понятных, уже сложившихся, образов в текстах. Следуя Саиду, исследователи стали выявлять, рассматривать и критиковать ложные репрезентации Востока в культуре Запада. К примеру, исследователи «русского ориентализма» обращают внимание на большое разнообразие репрезентаций Востока в 
российском обществе. Репрезентации, однако, приводят к забвению, не замечанию временной, географической и социальной и культурной дистанции с субъектами.

Например, называя обитателей Османской империи азиатами, т. е. отсталыми и т.п., многие российские авторы сами верили в истинность таких представлений. «Они» (турки) сводились к определенным (позитивным, либо негативным) образам. Чтобы избежать этой ошибки исследователи не должны затрагивать «проявление» объекта вне области репрезентации. Кроме того, необходимо помнить о дистанции, находящейся не по ту сторону, но до любых репрезентацией, т.е. о дистанции, которая заранее предопределяет любую репрезентацию. Иначе говоря, перенести центр тяжести на условия возможности становления и проявления репрезентации.

Не следует понимать репрезентацию как простое отражение некоего образа у субъекта (теория рефлективности) или, с другой стороны, полагать, что репрезентация создает из своего субъекта некий образ (социальный конструктивизм). Данные подходы предполагают и репрезентацию и ее

субъект, устанавливая между ними внешние отношения. Именно подход М. Фуко помогает снять внешние отношения между репрезентацией и ее субъектом (отношения произведение-автор), а также, не считая репрезентацию уже созданным образом, обратить наибольшее внимание на фундаментальные основы - историю, язык, социальные условия выражения.

Важнейшим этапом в становлении этой нового поля исследований стала Э. Саида «Ориентализм» (Said 1978), которая оказала сильнейшее воздействие на эволюцию всего гуманитарного знания. Эта работа стала основой новых дискурсов и практик. Как результат - появление концепции «инвенции традиций» Э. Хобсбаума и Т. Рейнджера, (Hobsbawm 1983: 1-14, Ranger 1993: 211-262), «воображаемых сообществ» Б. Андерсона (Андерсон 2002), «полуориентализма» Л. Вольфа. (Вульф 2003) С начала XIX века «востоковедение» в России воспринимается как некий корпоративный институт, созданный для того, чтобы представлять Восток, делать некоторые официально санкционированные утверждения относительно него, формируя взгляды на него, описывая его, изучая и побеждая его в войнах. Таким образом, «востоковедение» выступает как стиль доминирования, реструктурирования и властвования над Востоком. Для определения «востоковедения»/«ориентализма» вполне возможно применение понятие «дискурс», как оно предложено М. Фуко в его работах «Археология знания» и «Надзирать и наказывать» (Фуко 1996а, 1999b). 
Поэтому, как было сказано выше, Э. Саид, вслед за М. Фуко, понимал дискурс как комплекс высказываний, в совокупности конструирующих общий объект анализа, как специально артикулированное знание о данном объекте, как определенные взаимосвязи, имеющие регулярность, порядок и систематику. Следовательно, противопоставляя себя «Востоку» как субституту «Я», российское общество и культура выигрывали в силе и индивидуальности.

Основная цель статьи, таким образом, состоит в том, чтобы сфокусировать внимание на субъективно-психологических моментах имперского строительства: проблемах восприятия, мотивации, протекания межкультурных контактов. Следовательно, культурологический подход к проблеме призван ответить на вопрос, сформулированный еще Э. Саидом: «Как сложились те понятия и особенности в восприятии мира, которые позволили порядочным мужчинам и женщинам принимать идею, что удаленные территории и населяющие их народы должны быть покорены». (Said 1978: 5)

Таким образом, ставится задача критически проанализировать исследовательские возможности дискурса ориентализма на примере исследования процессов зарождения и развития концептов «азиатская роскошь», «азиатское/восточное красноречие», «восточная мудрость» как в области массовых представлений, так и политико-дипломатическом дискурсе; определить, в чем российский «Восток» и его репрезентации отличались от «Востока» европейских держав; охарактеризовать своеобразие и оригинальность российского имперского видения Востока.

Будучи в глазах Запада сама Востоком, Россия в силу своего географического положения и исторических традиций демонстрировала разные варианты восприятия военно-политического, дипломатического и социокультурного поведения в отношении восточных народов.

В качестве предметного поля для анализа указанных проблем представляется целесообразным использовать комплекс взглядов и высказываний россиян относительно Османской империи.

В начале XIX в. влияние западного ориентализма распространилось и на Россию. Восток стал заметной темой в русском литературнохудожественном дискурсе (А.С. Пушкин, М.Ю. Лермонтов, Л.Н. Толстой, Бестужев-Марлинский, В.И. Даль). В Российской империи стремительно развивалось востоковедение, а такие видные его деятели как В. В. 
Григорьев, В. П. Васильев, Н. И. Ильминский и другие служили российскому правительству. При этом, патерналистский колониальный контекст неизменно усиливался в описаниях восточных народов, хотя не была полностью забыта и традиция сотрудничества с соседями-мусульманами.

Противостояние Российской и Османской империй носило перманентный характер, что формировало и усиливало интерес российской читающей публики к Востоку. Так, когда в апреле 1828 г. началась русскотурецкая война, редколлегия газеты «Северная Пчела», рекламируя в июле того же года переводную книгу французского автора Ш. Деваля «Два года в Константинополе и Морее (1825-1826)», была уверена в ее успехе: ведь «кому из Русских не приятно будет познакомиться покороче со страною... в которой теперь у каждого есть... родственник или знакомый» (Северная пчела 1828: 12)

Русско-турецкие войны XVIII - XIX веков оказывали влияние на повседневную жизнь россиян. В первой половине XIX в. «обычай привозить с собою, после походов, спасенного от гибели турчонка или взятых в плен турчанок и дарить их своим родственникам на воспитание или в прислугу занес много примеси южной крови между нами» (Блудова 1889: 56).

Подобные же сведения содержатся в мемуарах П. П. Семенова-ТянШанского (1827-1914) (Семенов 1917: 68).

Тем не менее, дефицит достоверной информации даже о приграничных районах Азии сохранялся в первые десятилетия XIX в., несмотря на постоянство контактов между Россией и Востоком. Причем, даже на уровне официального дискурса, существовали и проявлялись достаточно смутные представления о том, что реально из себя представляют те или иные ее регионы.

Вопросы о политических принципах России по отношению к Османской империи, о частной собственности и о характере взаимоотношений государства и общества неоднократно поднимались Александром I и Николаем I, А. П. Ермоловым, М. М. Сперанским и Е. Ф. Канкриным, стремившихся разрешить проблемы, остро вставшие перед Россией в XIX столетии.

Разумеется, для того чтобы понять особенности отношений к Османской империи периода русско-турецких войн, потребовалось обращение к материалам предшествующего периода, так как многие тенденции в 
российско-османских отношениях и в понимании Востока россиянами были заложены еще в XVIII в. Вместе с тем, сравнительный анализ воззрений на Восток (Азию) россиян XVIII и XIX вв., позволяет выявить принципиально новые явления в общественной мысли России.

Прежде всего, необходимо выделить несколько основных социокультурных и политических факторов, определявших в начале XIX в. отношение россиян к Азии и Османской империи. В частности, для большинства жителей Западной Европы слово «Восток» означало прежде всего регион, отдаленный сотнями и тысячами километров. В России ситуация была иной. Российское государство с XVI в. взаимодействовало, а с XVIII в. включало в себя прежде османские территории, поэтому Восток никогда не был для россиян далекой экзотикой (даже для тех из них, кто жил на северозападе или в центре России).

К примеру, восточные торговцы стали к началу XIX в. привычными обитателями российских городов. В 1816 г. анонимный автор, описывая Летний сад и «гульбище подле Адмиралтейства», выделял в петербургской толпе таких людей, как «Арапы, Турки (курсив - наш, М.К.), Армяне, каждый в своем национальном наряде... Вот Англичане... вот Турки, вот Греки, вот Армяне... Я видал сих народов на картинах; здесь они в самой натуре...». (Дух Журналов... :559 (195) сл.)

Восток, таким образом, был представлен в России довольно широко и диахронически и синхронически. Отмечается постоянный интерес к Османской империи и Персии. Являясь политическими соперниками России, эти государства поддерживали с ней относительно стабильные дипломатические отношения. Однако, уровень репрезентации стран Востока был далеко не одинаков. Можно зафиксировать и неприкрытую неприязнь к Османской империи, и простое любопытство по отношению к обычаям восточных народов, и личные воспоминания ветеранов русско-турецких войн, и пересказывание вульгарных насмешек над исламом, отражавших, скорее всего, не столько неприятие мусульман, сколько характерную для западноевропейской общественной мысли эпохи Просвещения критическую тенденцию в духе Вольтера по отношению к религии как таковой.

Несомненно одно - в XVIII столетии концепт «Восток» уже постоянно присутствовал в сфере интересов российской власти.

Временной диапазон ориенталистского дискурса охватывал период от завоеваний Золотой Орды до эпохи Екатерины II. Следует отметить и 
обращение к историческому опыту России, относительно ее политических и дипломатических связей со странами Востока, что проявляется лишь в рассказах о поведении русских и восточных послов во время выполнения ими дипломатических миссий. В результате власть и общество получают некоторое смутное представление о дипломатической «кухне»: порядок приема восточных посольств и подготовки официальных документов в Коллегии иностранных дел, в составе которой в 1797 г., впервые была учреждена «экспедиция» для дел по сношениям с азиатскими народами.

Вместе с тем нельзя не отметить бессистемность и поверхностность информации об Османской империи. Как правило, это был устный, а не письменный дискурс, возникавший, например, с прибытием турецкого посольства, либо с рассказами людей, так или иначе столкнувшихся с восточным миром. То, что Восток и Турция были представлены довольно широко, не означает глубины и полноты информации о них.

Недостаток информации о Востоке в России в начале XIX в. обусловливался различными факторами. В частности, значительным препятствием для проникновения на Восток являлись огромные пространства самой России. Связи между частями империи были крайне затруднены, поэтому подготовка экспедиции или миссии на Восток требовала достаточно больших усилий и материальных затрат.

Публикации в российской прессе позволяют понять, что конкретно было привнесено в понимание Турции российским обществом в первой половине XIX в., а также, каким образом в этот период распространялась информация об Азии в целом. Периодическая печать приобрела важную роль в общественном сознании изучаемой эпохи. Эпоха «печатного капитализма» наступила в России значительно ранее, чем капитализма, собственно, экономического, хозяйственного. Постоянные конфликты России с Персией и Османской империей - эти политические события, затрагивавшие жизнь многих россиян, побуждали их внимательно следить за сообщениями в газетах и журналах.

С одной стороны, издатели следовали вкусам своих читателей, с другой - сами подогревали их интерес к Османской империи как составной и неотъемлемой, как считалось, части Востока. Благодаря этому новейшие «востоковедческие» исследования находились в тот период в центре общественного внимания. 
Так, в ноябре 1828 г. «Коммерческая Газета» перепечатала статью, в которой приводилось мнение, что окончательная победа Российской имприи над Османской «восстановит существовавшие прежде между Азиею и Европою торговые сообщения, обратит на древнюю сухопутную дорогу большую часть производящейся ныне чрез Английские Ост-Индские владения Азиатской торговли и освободит Европейский рынок от тягостной монополии Англичан и от торгового их первенства». (Комерческая Гезета 1828)

В 1841 г. Булгарин все еще надеялся, исходя из просвещенческой, по сути, идеи о географическом детерминизме, что Россия вследствие удобного географического положения приобретет ведущее положение в европейскоазиатской торговле. (Булгарин 1841: 17 - 18)

В целом же, если углубиться под внешний покров российской ориентальной идеологии и политики и взглянуть на грамматику, в соответствии с которой они с начала XIX в. развивались, то ситуация проясняется. Мало что демонстрирует так рельефно эту грамматику, как те властные институты, которые, были изобретены еще до начала XIX в. Этими институтами, как уже отмечалось выше, стали статистический учет населения и картография: они глубоко повлияли на то, как Российская империя созерцала в воображении свои окраинные и сопредельные пространства природу людей, которыми она правила, географию своих владений, легитимность своего происхождения.

Исследование схем восприятия, оценивания и действия, характерных для российской высшей военной и гражданской бюрократии это убедительно показывает. Образцы «категорий идентичности», собранные из документов, конца XVIII в. и вплоть до середины XIX в., демонстрируют необыкновенно быстрый и с виду произвольный ряд изменений, в котором эти категории постоянно соединяются воедино, затем вновь распадаются на части, заново комбинируются, смешиваются друг с другом и перегруппируются. Из этих статистических и географических обзоров следует два основных вывода. Вопервых, пока продолжался период военно-политического и дипломатического противостояния с Османской империей, категории становились все более наглядно этническими и политическими. Религиозная идентичность, в свою очередь, постепенно утрачивала роль первоочередной учетной классификации. Эти «идентичности», рожденные воображением классифицирующего умов военной и гражданской бюрократии государства, еще только ожидали своей реификации, которая вскоре стала возможна. Кроме того, можно заметить стремление изготовителей обзоров к завершенности и однозначности. Отсюда их нетерпимость к множественным, политически неясным и изменчивым 
идентификациям. Замысел состоял в том, чтобы каждый попал в обзор и имел в нем одно - и только одно - абсолютно ясное место. Тем не менее, Российской империи часто приходилось сталкиваться с реалиями, доставлявшими ей неудобства. Важнейшей среди них была, несомненно, религиозная принадлежность, служившая основой очень старых и стабильных воображаемых сообществ.

Если российский путешественник первой половины XIX века преодолевал грандиозные пространства России, проникновение на Восток оставалось для него делом крайне сложным. Россия граничила с враждебными Османской империей и Персией, так что о проведении российскими путешественниками научных экспедиций на их территориях в то время не могло идти и речи. Так что, увидеть Восток «изнутри» удавалось очень немногим, и сведения, доставлявшиеся этими людьми, зачастую носили сбивчивый, бессистемный характер.

Недостаток достоверных знаний об азиатских государствах долгое время не позволял адекватно оценить уровень развития этих стран, их экономический и военный потенциал. В частности, это невозможно было сделать из-за отсутствия хотя бы приблизительных данных о количестве проживавшего там населения. Цифры, приводившиеся различными исследователями в отношении одной и той же страны, зачастую различались в несколько раз.

Так, 29 сентября 1828 г. в «Северной Пчеле» была перепечатана из французского журнала заметка «О народонаселении Турции», где выражалось сомнение по поводу точности статистических данных об Османской империи.

(Северная Пчела 1828)

Через некоторое время после возвращения какой-либо экспедиции из Азии, как правило, выходила книга с записками одного из участников этого предприятия (примером могут служить произведения Е. Кайдалова, Е.Ф. Тимковского, Н. Муравьева). Эти работы распространялись посредством рецензий в прессе. (Булгарин, 1822)

Фрагменты из подобных записок путешественников чаще всего публиковались в «Северном Архиве» (Мейендорф, 1824), в научных исследованиях (Френ, 1826; Эрдман, 1828), турецкие исторические хроники также публиковались в исследованиях российских авторов. (Сенковский, 1826) С одной стороны, издатели следовали вкусам своих читателей, с другой - сами активно поддерживали их интерес к Османской империи. 
В репрезентации Востока важную роль играло стереотипное представление об «азиатской роскоши». В. В. Бартольд, проследив генезис этого концепта античную эпоху, пришел к выводу, что «представление об азиатской роскоши неразрывно было связано с представлением об азиатском деспотизме».

Европейцам, в том числе Пушкину, «бросалась в глаза только азиатская бедность» (Бартольд 1966: 404).

Однако, за рамками статьи Бартольда остались конкретные проявления этих представлений, также как и особенности восприятия «азиатской роскоши» в России.

Отметим, что понятие «роскошь» имело в XIX в. два основных значения. Первое - эстетическое, подразумевавшее «изящное», «прекрасное». Второе значение имело в виду «избыток», т. е. «все, что сверх известной меры», было значительно ближе к его современному пониманию. Например, Шторх определял роскошь как «понятия и желания наслаждений свыше первоначальных житейских нужд» (Шторх 1881: 19-20).

Естественно, что между представлением о «прекрасным» и жизнью «утонченной и извращенной» - большая разница. Различные аспекты этого понятия порой тесно переплетались друг с другом, запутывая читающую публику так, что приходилось догадываться об истинном значении того или иного высказывания.

Сведения об «азиатской роскоши» попадали в Россию самыми различными путями. Например, о ней рассказывали те, кому довелось побывать в восточных странах. Речь идет о дипломатах, путешественниках, пленниках и т.д. Во всяком случае, некоторые государственные деятели не сомневались в великолепии восточных дворов. Российский офицер Н. М. Клемент, оказавшись в турецком плену, прожив в Стамбуле два месяца, писал, что издали город как будто «покрыт золотою сетью». Большое впечатление на него произвели золотые ковши, подвешенные на золотых цепочках на мраморных фонтанах в окрестностях Стамбула. (Клемент 1823: 283-284)

Другой пример: анонимный автор в своем «Письме русского из Константинополя», описывая одну из церемоний, происходивших в столице Османской империи, заметил: «Султаны при сем обряде оказывают все великолепие Восточной роскоши» (Северная Пчела 1828: № 59) 
Председатель Казанского общества любителей отечественной словесности Г.Н. Городчанинов, в сочиненной им по случаю торжественного собрания в Казанском университете в 1816 г., оде «Плоды благословенного мира» так фактически реифицировал концепт «Азия» (Казанские Известия 1816: 299):

в драгоиеннейшем тюрбане,

В алмазов, яхонтов лучах,

На злато-иелковом диване

Иль на узорчатых коврах Свочх изделиях персидских,

В одежде из тканей Ост-Индских Роскошна Азия сидит...

Следует заметить, что представления о «восточной роскоши» возникали не только под влиянием художественной литературы и записок тех, кто побывал на Востоке. Привезенные в Россию дорогие кашмирские шали, военные трофеи в драгоценного оружия и ювелирных изделий, способствовали распространению мнения о «роскошной жизни Азиятцев» в самых широких слоях российского общества. (Пушкин Ан. 1826: 265, Бестужев-Марлинский 1847: 133-134)

Предпринимались попытки связать явление «азиатской роскоши» с некоторыми особенностями устройства всех восточных обществ. Так, в одной статье «Северного Архива» роскошь трактуется как образ жизни, свойственный всем азиатским народам: «Роскошная жизнь Азиятцев, их празднолюбие и равнодушие ко всему лучшему казались нам всегда неизбежною болезнью, общею всем Восточным народам, сколько потому, что она в равной силе свирепствовала... при Соломоне и Ксерксе, при Крезе, при Турецких султанах (курсив - наш, M.К.) и раджах Индийских, столько и потому, что самые отважные завоеватели... арабы и монголы через несколько времени после своих геройских подвигов какою-то непреодолимою силою вовлекались в подобную же роскошь и негу» (Рашков 1826: 202).

Причину такой «болезни» автор пытается объяснить природными условиями азиатских стран, т. е. сводит все к «природному», «естественному», следовательно, неизменному, отсталому и косному. В результате «Восток с незапамятных времен остается при своих старых обычаях: в нем ничего существенно не переменилось, и образ мыслей прадедов виден во всех 
поступках позднейшего потомства». Таким образом, для Рашкова категория «роскошь» определяет наиболее важные аспекты бытия восточных обществ.

Часто стереотипное восприятие констатируемой взаимосвязи роскоши и восточного деспотизма приобретала даже комический оттенок. Например, в нравоучительном «восточном» рассказе Булгарина «Человек и мысль» судья (кади) обращается к своей жене со словами: «Сокрой от глаз моих твои прелести, которые я старался украшать драгоценностями, купленными слезами народа». (Булгарин, 1839-1844: 64)

Репрезентации Востока, сформированные литературно-художественным дискрсом, редко выдерживали испытание при соприкосновении с объективной реальностью. Оказавшись на Востоке, россияне пытались обнаружить признаки «азиатской роскоши», но мало кто из них не испытал, чувства глубокого разочарования.

Этапным периодом в развитии представлений об «азиатской роскоши» стала русско-турецкая война 1828-1829 гг. Многие офицеры русской армии пытались сопоставить собственные представления о Востоке со своими непосредственными впечатлениями. Так, подполковник Радожицкий, посылавший письма с театра военных действий в «Северную Пчелу», встречался в Арзруме с Пушкиным. Характерно, что офицер увидел в этом городе тоже, что и великий поэт: не «богатства», а кривые узкие улицы, невзрачные фонтаны, сломанные башенные часы, покрытые ржавчиной древние доспехи в арсенале; не богатейший город Азии, а городок, который «в обширности своей... уступает даже нашему Курску», не пленительных гурий, а «живых мумий» в белых чадрах, «как в саванах», не «азиатскую роскошь», а «азиатское невежество». (Радожицкий 1829: 13, см. также Тартаковский 1991: 148-151)

Близкий знакомый Пушкина, А.Н. Вульф, принимал участие в русскотурецкой войне на балканском театре военных действий. В сентябре 1829 г. он присутствовал на переговорах между верховным визирем и представителями командования русской армии в Шумле. Вульф записал в дневнике: «...подали трубки и кофей. Длинные черешневые чубуки были с красивыми янтарями... кофейные чашечки у турок... подаются вставленные в другие, металлические; последние у Визиря были также украшены каменьями... . Вот все, что я нашел похожего на роскошь у первого сановника Порты. Одежда его была проста...». (Вульф 1916: 76) 
В 1836 г. в первом томе журнала «Современник» впервые опубликовано «Путешествие в Арзрум». В главе пятой содержалась, ставшая впоследствии известной, фраза: «Не знаю выражения, которое было бы бессмысленнее слов: азиатская роскошь... Ныне можно сказать: азиатская бедность, азиатское свинство и проч., но роскошь есть, конечно, принадлежность Европы. В Арзруме ни за какие деньги нельзя купить того, что вы найдете в мелочной лавке первого уездного городка Псковской губернии». Можно сказать, что это высказывание стало квинтэссенцией, итогом размышлений целого поколения писавших и размышлявших об Азии/Востоке/Турции, россиян.

Естественно то, что суждения Пушкина пользовались авторитетом, и с конца 1830-х годов насмешка над «азиатской роскошью» становится таким же общим местом в «восточных» записках россиян, каким до того времени было неизменное упоминание о роскоши Востока в литературе и периодике.

Такова была общая тенденция развития представлений об «азиатской роскоши» в российском ориентальном дискурсе дореформенного периода: уверенность в существовании «азиатской роскоши» под влиянием непосредственных контактов с Востоком трансформировалась, под воздействием реальности, в представление об «азиатской бедности».

А. С. Пушкин воспринимал понятие «роскошь» как нечто прекрасное, замечательное, так же, как Бестужев-Марлинский относил «восточную роскошь» к области эстетики. (Бестужев-Марлинский, T. IV: 168-169)

Именно двойственностью данного понятия объясняются явные (на первый взгляд) противоречия в трактовке «азиатской роскоши» разными авторами, а часто одним и тем же сочинителем. Эта двойственность позволила Булгарину, публиковавшему Радожицкого, который описывал Арзрум в самых мрачных тонах, год спустя в книге «Картина войны России с Турциею...» восхищаться «русскими орлами», воевавшими «за хребтами неприступных Балканов, под стенами древней столицы Оттоманов и в роскошных долинах Арзрумских». (Булгарин, 1830: 44)

Эпитет «роскошные» в данном случае подразумевал не столько переизбыток материальных благ у жителей Арзрума, а красоту горных пейзажей.

Противоречия в трактовке данного понятия объясняются еще и тем, что сама реальность была совсем не однозначна. К.М. Базили в своей книге, посвященной описанию Стамбула, упоминая о том, что «утонченная 
Азиятская роскошь несказанно возвышает всякое чувственное удовольствие», отмечал неопрятность жителей города. По его мнению, «Европейская роскошь в белье туркам совершенно неизвестна». (Базили 1836: 6, 94)

Мы наблюдаем типичный пример доказательства превосходства доминирующих над доминируемымими - констатация бытовой, внешней, телесной скудости, нищеты и неустроенности, как неизменного атрибута отсталости, требующей покровительства, исправления и устранения.

Следовательно, только в зависимости от интенций своего сочинения, автор мог акцентировать внимание либо на «азиатской роскоши», либо на «азиатской бедности».

Вышеуказанные факторы определили устойчивость рассматриваемого концепта, и, несмотря на некоторую трансформацию взглядов россиян - речь идет о появлении описаний «азиатской бедности», - представления об «азиатской роскоши» все же продолжали существовать и в дальнейшем.

Представления, аналогичные «азиатской роскоши» были свойственны многим в России и относительно концепта «восточное красноречие». В первые десятилетия XIX в. в российском ориенталистском дискурсе существовало представление о том, что на Востоке принято изъясняться (писать), пересыпая речь (текст) аллегориями, метафорами, стихами, отчего даже обыкновенное приветствие превращается в литературное произведение.

Можно назвать несколько источников формирования этого стереотипа. для составления официальных документов, предназначенных восточным правителям, в качестве образца использовались послания тех же восточных правителей в адрес российских монархов или высоких сановников. Например, А. Н. Муравьев, побывавший в 1830 г. в Египте, приветствуя Мухаммеда Али, попросил переводчика «изъяснить Паше, как сладостно... быть в областях его эхом нашего великого народа, исполненного уважения к светлому преобразователю сих древних стран, которого благодатная рука - как второй Нил для Египта». (Муравьев 1832: 127)

Эта традиция велеречивых изъяснений продолжала сохраняться и в 1830-е годы. Каковы были реальные результаты попыток использовать приемы «восточного красноречия»?

Структурно очень сложные, витиеватые, с нашей точки зрения, выражения, употреблявшиеся на Востоке в дискурсе доминируемых по 
отношению к доминирующим, не столько удовлетворяли эстетические запросы последних, сколько четко фиксировали иерархически выстроенные нормы социальных отношений. С одной стороны, такая форма обращения еще раз подтверждала незыблемость существующей власти, с другой предоставляла возможность создать у правителя благосклонное настроение по отношению к своему подданному. Следовательно, за пределами данной системы взаимоотношений, восточное красноречие утрачивало свой смысл и значение социально маркированной дискурсивной практики.

Уже к концу 1830-х стало очевидно, что добиться коммуникативного взаимодействия с обществами Востока с помощью «неуместной затейливости», будет невозможно в силу различия культурных и языковых кодов, особенно используя сконструированные и усвоенные самими россиянами литературными штампами и стереотипами. Уже «Путешествие в Арзрум», вышедшее в свет в 1836 г., отражало новую тенденцию в российском ориенталистском дискурсе. Салтыков в 1838 г. отзывался о восточном красноречии как о наборе банальностей, за которыми скрывается отсутствие какого-либо содержания. (Сопленков 2000: 63)

Наряду со стереотипом восточного красноречия у россиян сложилось представление о восточной мудрости. Восточная мудрость это изречениеафоризм, подобное морали в баснях, употреблявшееся, как правило, в нравоучительных целях. В связи с тем, что для афористических выражений характерна метафора, восточная мудрость превращалась в миниатюрный образчик восточного красноречия, так, что оба этих представления развивались параллельно.

Концепт «восточная мудрость» складывается задолго до ХІХ в. В первые десятилетия XIX столетия обращение к восточной мудрости было стимулировано статьей Уварова «Мысли о заведении в России Академии Азиатской», где провозглашалось: «Азия есть то средоточие, из которого истекло просвещение, разлившееся по всему земному кругу...» (Уваров 1811: 28)

Восточная мудрость в представлении читателя была связана с образом восточного правителя, в чьих устах она становилась как бы еще более мудрой. 10 марта 1828 г. в «Московских Ведомостях»[Московские Ведомости 1828: 879)

можно было прочитать, что «Паша Египетский, как сказывают, принял известие о Наваринском сражении с величайшим равнодушием. «Я не 
сожалею о кораблях, - сказал он, - ибо могу построить новые, но весьма жалею о потере людей». Эта фраза соответствовала образу мудрого правителяреформатора, каким представлялся Мухаммед Али многим россиянам в первые десятилетия XIX в.

Разочарование в деятельности восточных реформаторов разрушило и данный стереотип. Восточная мудрость со временем начала восприниматься как вычурная тривиальность, скрывающая отсутствие глубокого смысла в словах. Очень ярко это сказалось на восприятии личности того же Мухаммеда Али. Если в 1830 г. А. Н. Муравьев восхищался его мудростью как реформатора, то десятилетие спустя попытки египетского паши изрекать философские суждения вызывали у Базили только иронию. (Базили: 178)

Стереотипы восточного красноречия и восточной мудрости сформировались в условиях дефицита достоверной информации о социальноэкономических аспектах жизни восточных обществ. Метафоры-аллегории, поэтические обороты, характерные для стиля не только восточных литературных произведений, но и посланий азиатских правителей, были наиболее яркими деталями незнакомой культуры, и на них акцентировалось внимание европейцев. У человека, овладевшего языком иносказаний и метафор, возникала иллюзия приобщения к чуждой ему культуре, что давало ему надежду на установление взаимопонимания с обитателями Востока. При этом из виду упускался сложный комплекс социально-политических особенностей деспотии. Увлечение внешней оболочкой восточной культуры не позволяло проникнуть в ее сердцевину, не могло сыграть решающей роли в успехе контактов России с Востоком.

Каким бы наивным ни казалось нам стремление россиян с помощью восточного красноречия добиться взаимопонимания с жителями азиатских государств, данная тенденция, сложившаяся в первой половине XIX столетия, весьма симптоматична. В одном из документов был сформулирован принцип, которому в дальнейшем следовали многие российские представители на Востоке в тех случаях, когда местные традиции не противоречили их морально-этическим нормам: «Мы нашлись приспособиться несколько к их предрассудкам» (Архив Внешней Политики Российской империи 1816: 49).

Можно сазать, перефразируя Э. Саида, что Османская империя, да и весь Восток, были не собеседником России, «а ее безмолвным «Другим». (Саид: 17) 
В итоге, констатируем факт, что особенности социально-политического и культурного своеобразия Востока интересовали россиян не как объекты экзотики, а как насущные проблемы, плотно переплетенные с вопросами, стоявшими перед всем российским обществом. 


\section{Библиография}

Ballantyne T. Empire, Knowledge and Culture: From proto-Globalization to Modern Globalization // Globalization in World History. L., 2002.

Colonial Discourse and Post-Colonial Theory: A Reader. N.Y., 1994.

Colonial Discourse, Postcolonial Theory. Manchester, 1994.

Hobsbawm E. Introduction: Inventing Tradition // The Invention of Tradition. Cambridge, 1983.

Kennedy D. Imperial History and Post-Colonial Theory // The Journal of Imperial and Commonwealth History. 1996. Vol. 24, № 3.

Ranger T. O. The Invention of Tradition in Colonial Africa // The Invention of Tradition // Legitimacy and the State in Twentieth-Century Africa. L., 1993.

The New Cultural History. Berkeley, 1989.

The Post-Colonial Studies Reader. L., 1995.

Said E.W. Orientalism. N.Y., 1978.

Washbrook D.A. Orients and Occidents: Colonial Discourse Theory and the Historiography of the British Empire // The Oxford History of the British Empire. Vol. 5. Historiography. Oxford, 1999.

Андерсон Б. Воображаемые сообщества. М., 2002.

Архив Внешней Политики Российской империи. Ф. 161. Главный архив, paзp. I-7. 1816 г. Д. 1, папка 11. О посольстве генерал-лейтенанта Ермолова в Персию.

Базили К. М. Босфор и новый очерки Константинополя. Соч. Константина Базили. Ч. 1. СПб., 1836. 1966.

Бартольд В. В. Азиатская роскошь. Бартольд В. В. Сочинения. T. IV. М.

Бестужев-Марлинский А. Военный антикварий: из Арзрума, 1829 года в октябре. Второе полное собрание сочинений А. Марлинского. 4-е изд. СПб., 1847.

Блудова А.Д. Воспоминания графини Антонины Дмитриевны Блудовой (писаны в 1867 году) // Русский архив. 1889, кн. 1. №1. 
Булгарин Ф. Разбор книги по заглавием: Путешествие в Туркмению и Хиву // Северный Архив, 1822, ч. 2, №11, 12, ч. 3, № 13.

--. Картина войны России с Турциею в царствование императора Николая І. СПб., 1830.

--. Янычар или Жертва междоусобия. Полное собрание сочинений Фаддея Булгарина. Т. 5. СПб., 1839-1844.

--. Русские письма о торговле и [о] фабричной и мануфактурной промышленности. Письмо II. Эконом. СПб., 1841, тетр. 2.

Вульф А. Н. Дневник А. Н. Вульфа: 1828 - 1831. Пушкин и современники: Материалы и исследования. Т. 6, вып. XXI - XXII. Пг., 1916.

Вульф Л. Изобретая Восточную Европу: карта цивилизации в сознании эпохи Просвещения. М., 2003.

Дух Журналов. 1816, ч. XIV, кн. 39.

Казанские Известия. 1816, № 61.

Клемент Н. М. Записки русского офицера о плавании в Средиземном море и о пребывании в плену у албанцев и турок // Северный Архив. 1823, ч. 7, № $17-18$.

Коммерческая Газета, 1828, № 44.

Мейендорф Е.К. Отрывок из «Путешествия в Бухарию полковника барона Мейендорфа в 1820 и 1821 годах // Северный Архив 1824, ч. 9, № 1 - 3.

Московские Ведомости, 1828, № 220. 1832.

Муравьев А. Н. Путешествие по святым местам в 1830 году. Ч. 1. СПб.,

Пушкин Ан. Взгляд на военное состояние Турецкой Империи // Сын Отечества. 1826, ч. 107, № $9-11$.

Радожицкий Ил. Письма из Арзрума // Северная Пчела. 1829, № 135,136.

Рашков Н. Образ войны Англичан в восточной Индии // Северный Архив. 1826. Ч. 19, № 2.

Северная Пчела, 1828, № 59. 
Северная Пчела, 1828, № 117.

Северная Пчела, 1828, № 87, прил. «Объявление».

Семенов-Тян-Шанский П. П. Мемуары. Т. 1, Пг., 1917.

Сенковский. Посольство Дервиша-Мухаммед-Эффендия В Россию в 1163 году эгиры [хиджры] (после 1755 Р. Х.) // Северный Архив. 1826, ч. 19, № 1.

Сопленков В. В. Дорога в Арзрум: российская общественная мысль о Востоке. М., 2000.

Тартаковский А. Г. Русская мемуаристика XVIII - первой половины XIX в.: От рукописи к книге. М., 1991.

Уваров. Мысли о заведении в России Академии Азиатской // Вестник Европы. 1811, ч. 55, № 1. $-15$

Френ. Восточные известия о Руссах // Северный Архив. 1826, ч. 22, № 14

Фуко М. Археология знания. М., 1996

--. Надзирать и наказывать. М., 1999.

Шторх А. К. Курс политической экономии или Изложение начал, обусловливающих народное благоденствие. СПб., 1881. № 9 .

Эрдман. О походе Руссов против Берды // Северный Архив. 1828, ч. 35, 